\title{
1. Is the flying-geese theory passé - or still relevant?
}

\subsection{THE 'FLYING-GEESE (FG)' ANALOGY}

Before the Asian crisis broke out in July 1997, the analogy of 'a flyinggeese (FG) formation' (ganko keitai in Japanese) had been frequently used with enthusiasm to describe the sequential pattern of rapid growth and structural upgrading in East Asia. The popular description went that Japan led the gaggle, followed by the NIEs, which were in turn pursued by the ASEAN-4 and China - all soaring together up the ladder of economic development. This string of 'tandem growth' (Ozawa, 1995, 2005) was once the admiration and envy of the world. The World Bank (1993) even called it 'the East Asian Miracle'. In the wake of financial turmoil, however, such a metaphor lost its power of depiction. After all, the Asian flock fell from the sky disgracefully. Yet, the crisis-stricken quickly rebounded with burgeoning trade surpluses. Together with the galactic rise of China and India, Asia is presently again the center of attention in the world.

The poetic allegory of 'flying-geese formation' was originally introduced in the 1930s by Professor Kaname Akamatsu of Hitotsubashi University, Tokyo, to describe his theory of industrialization in developing countries (inter alia, Akamatsu, 1935, 1937). Although the FG theory was already well known in Japan, it only began to be accepted outside the country after East Asian growth had gotten worldwide attention during the 1970s. Above all, it caught the fancy of policymakers, particularly after Saburo Okita, former Japanese Foreign Minister, had made reference to it at the fourth Pacific Economic Cooperation Conference in Seoul in 1985.

The media soon adopted this catchy phrase and popularized it. For example, observing the Asia Pacific in 1989, The Economist, wrote:

When geese migrate, they fly in a V-formation. The pattern is a favourite analogy of Japanese civil servants for the economic development of East and South-East Asia. Japan leads. Behind it follow the [NIEs]. In the third rank are [ASEAN-4] and coastal China. As with flying geese, the arrangement is purposeful, well-ordered and coordinated. ${ }^{1}$

The analogy has so far been used mostly in a casual way as a shorthand depiction of the staggered growth sequence of a number of closely clustered 
economies in East Asia. But there has been little reference to theoretical explanations of why such tandem growth occurs. For that matter, no analysis has yet been made of how the FG formation for economic development was causatively related to, and ultimately culminated in, the Asian financial crisis of 1997-8.

Actually there is another metaphor that is worth mentioning here, the one used in 1996 by Lee Kuan Yew, former Prime Minister of Singapore (1959-90), to describe East Asia's clustered growth. In answering a reporter's question, 'What created the economic success across Asia?' Lee gave the following reply:

I think the basic underlying reason for the success is the people, who are disciplined, take education seriously - especially mathematics, science and engineering - and have cultural habits of high savings and high investments, always working for the next generation. Then came the rapid spread of this industrialization process. It accelerated with the Plaza Accord in 1985, which pushed up the yen, then forced the Korean won and the Taiwanese dollar and the Singapore dollar up. This forced the relocation of Japanese industries to the newly industrialized economies, from these economies to the rest of Southeast Asia, then China, Vietnam and now Myanmar. This had a cascading effect. ${ }^{2}$

Lee thus employed the cascade metaphor instead. His observation is about the relationships between 'upstream' and 'downstream' countries in the cascade - instead of the 'leader and follower geese' analogy. Yet the essence is the same. ${ }^{3}$ What is particularly interesting is that Lee explicitly credited Asian success to: (i) human capital formation (especially in mathematics, science, and engineering), (ii) high savings and high investments, (iii) the rising values of Asian economies' currencies as a factor in industrial migration, and (iv) the sequential relocation of industries first from Japan to the NIEs, and then, from the NIEs to the rest of Asia. In this respect, Lee actually put his finger on some crucial linking mechanisms of the "cascading' phenomenon of clustered growth (these and other mechanisms are discussed in later chapters).

\subsection{RELEVANCY}

\subsubsection{A Hierarchy Matters: Dynamics of Growth Clustering}

Nowadays we hear so often that the FG theory of economic development, though once popular about two decades ago, is a thing of the past and is no longer pertinent as a way of explaining today's Asian economic growth. Yet, when it is elaborated on and reformulated as is done in this book, the 
FG model still serves as quite a useful frame of analysis - say, to define the 'ladder of economic development' and examine poverty reduction, infrastructure development, the growth patterns of financial markets, the reverse flow of capital - and even recent soaring commodity prices, as will be seen in the following chapters.

At the outset, however, it is important to keep in mind that the FG paradigm is based on a hierarchical multi-layered economic structure of intercountry relationships between leaders and followers - that is, to put it bluntly, between 'unequals'. They are at different stages of industrial development and sophistication. Perhaps this notion of hierarchical relationship, even if a temporary and passing phenomenon, seems to be ideologically offensive to (i) those who staunchly believe in the 'politically correct' idealism of total equality with no basis for hierarchical ranking, or (ii) some pure neoclassical economists who have no interest in political economy and who do not see economic agents and their activities in hierarchical terms.

In the realm of global economic growth, nevertheless, unequal positions, notably in knowledge creation and accumulation, can be a valuable resource for both leaders (path-breakers) and followers (emulators), because they generate economies of concatenation. Indeed, it can be argued that the world history of economic development is nothing but a repeated history of industrial leadership and subsequent emulation. The world never grows smoothly and evenly; it grows only in fits and starts; some lead, others follow; they often trade places. Historical accidents and politico-institutional forces trigger chains of cumulative causation, in both directions; sparking economic growth at some times and slowing down or even halting progress at other times. A hierarchy may become steeper or flatter. No particular country, however, can retain its dominant power forever without challenges from other countries or is condemned forever to the bottom of the hierarchy (that is, the pre-industrial state of underdevelopment).

Nowadays it is often said that the FG theory no longer holds, since there is no longer a powerful leader in the global economy. The argument goes that the industrial power of the lead goose, the US, as well as that of the second goose, Japan, has declined relative to other countries, notably the NIEs and BRICs (Brazil, Russia, India, and China), and that the global economy no longer grows top-down in a trickle-down fashion as envisaged by the FG theory of tandem growth. In other words, the post-World War II hierarchy of countries, in which the US was once indisputably the world's strongest and most powerful economy, has eroded to such an extent that no industrial hegemony prevails. True, we no longer live in the global economy where learning and growth opportunities were uni-directionally handed down from more advanced to less advanced countries. Growth stimuli move in both directions. Yet, there still exists a 
hierarchy of countries, even though it is no longer as steep as it used to be. The world economy has become increasingly homogeneous in many ways; the world has 'flattened'. We are in a period of 'hierarchy leveling' (or 'industrial homogenization') rather than 'hierarchy raising' (or 'industrial heterogenization'). (As will be made clear in Chapter 2, Akamatsu foresaw the alternating periods of heterogeneity and homogeneity in economic structure among countries).

\subsubsection{Misconception No. 1: Japan is the Lead Goose}

There are some misconceptions and misunderstanding about the FG paradigm that need to be dispelled. To begin with, the FG paradigm is interpreted in such a way that Japan is looked upon as the lead goose that single-handedly shapes and controls the rest of the Asian flock. The Economist's and Lee's observations quoted above are the prime examples. Sure, Japan has been a significant contributor to regional growth, both psychologically (via the 'demonstration effect' as Asia's first economic superpower) and commercially (as a key provider of industrial knowledge and industrial inputs). But its role has actually been as second goose under the aegis of US-led global capitalism. Japan is not quite the hub of Asian growth. All other Asian countries have also strived to catch up directly with the advanced West rather than with Japan. The former has been imparting industrial knowledge and accepting Asian exports more open-mindedly and more willingly than Japan.

In this regard, Pempel (1996/7, p. 16) caustically observes:

... Heading a 'flying V' of Asian economic geese, Japan would pull the region forward with its own successes in industrialization and manufacturing. The other Asian countries would follow Japan's lead and a succession of Asian 'geese' would replicate Japan's developmental experiences, and that of the other 'geese' ahead of them in formation, all moving steadily forward in their levels of manufacturing sophistication.

... Japan, of course, would remain the country destined to lead all regional development and would control all leading technologies and industries, but by following Japan's lead along a common trajectory, other countries would quickly benefit.

... The implicit arrogance of a permanent place at the front of the avian Asian advance seems never to have been challenged by most Japanese advocates of the model ...

On the contrary, indeed, Japan has been a follower goose riding on America's long coat-tails. The FG formation in Asia has been a creation of US-led 
growth clustering, though Japan no doubt played a key role as the second goose in Asia. The US is truly the lead goose whom Japan eagerly emulated as a latecomer. This point was also made clear in Okita's speech: 'In the Pacific region, ... the United States developed first as the lead country. Beginning in the late 19th century, Japan began to play catch-up development in the nondurable consumer goods, durable consumer goods, and capital goods sectors in that order' (Okita, 1985, as cited in Kojima, 2003, p. 31).

Moreover, the implied 'permanence' of Japan's position is certainly never guaranteed. The NIEs - and now China in particular - have been swiftly closing the development gap vis-à-vis Japan. This is particularly evident in some specific industries, such as computers, semiconductors, cell phones, and finance. Japan can never keep its emulators behind forever. Eventually, if not immediately, Japan will meet the same fate as Great Britain which was challenged and eventually bested by other Western nations. After World War II, the US has likewise been caught up with, if not yet fully, by Japan and other challengers. No permanence is the essence of FG formation (more on this in Chapter 2).

In short, industrial dynamics across Asia is a reflection of the evolution of modern capitalism that originated in the West and is presently driven largely under American leadership. Asia's economic vicissitude has stemmed from both the growth stimuli and the disequilibrating forces of hegemon-led global capitalism.

\subsubsection{Misconception No. 2: A Master Plan}

A second misinterpretation, as a corollary of the first, is that 'the arrangement is purposeful, well-ordered and coordinated', as noted in the abovecited quotation from The Economist. It implies some sort of a master plan behind the scenes. But Japan has had no master plan - for that matter, nor does the United States as the first lead goose. True, individual countries are inevitably engaged in economic policies and strategies. Some use industrial and innovation policies to facilitate their industrial upgrading. Nevertheless, US-led growth clustering itself - as the powerful undercurrent of global growth - is basically driven by market forces, though political motivations and actions are always behind it. It is the logic of capitalism and the reactions of participating countries that shape the seemingly 'purposeful' pattern of tandem growth. In fact, the US itself is often at the mercy of global capitalism, which dramatically and relentlessly alters its own economic structure. There is a rising backlash even in the US against the forces of globalization it has unleashed as its economic leadership in the world is being eroded, its comparatively disadvantaged industries abruptly contract at home, and jobs are offshored. 
What is more, the FG formation as seen in Asia is essentially a historical 'accident'. Over many centuries, a myriad of confluent forces have been converging in such a fashion as to advance global capitalism. It emanated most strongly from the Industrial Revolution in England. Such capitalist momentum is currently pushing forward across the Asian Pacific, inducing its economies to advance in tandem growth - and even plunge in tandem crisis as witnessed during the 1997-8 Asian financial débâcle and most recently in the fall of 2008. It is certainly not 'purposeful, well-ordered, and coordinated'. It is, in fact, at the mercy of market whims and subject to 'maniacs, panics, and busts' (Kindleberger, 1996), as will be discussed in Chapter 7.

\subsubsection{Misconception No. 3: The Unique Asian Phenomenon}

A third major myth is that the phenomenon of FG formation is something uniquely Asian and unprecedented. It is, however, neither peculiarly Asian nor new. A spread of concatenated industrialization across borders - indeed, a significant FG formation - once occurred throughout the Western world, both the Old and the New World, with Great Britain as the lead goose. The Industrial Revolution in England ushered the world into a modern economy fundamentally built on science and technology, propagating industrialization in the rest of the world. Continental Europe succeeded in industrializing by following Britain's footsteps (Landes, 1969) through commercial contacts and conscious efforts at emulation and learning. France and Belgium and then Germany served as the region's second geese, relaying modern industrial skills and surplus capital to others - and even remote corners of Europe. At that time, individual artisans and technicians possessed superior knowledge, which was transferred abroad through visitations or migration. Prior to the English hegemony, the changing fortunes of Florentine, Venetian, Genoese, and Dutch capitalism (Arrighi, 1994) also attest to the universality of FG formation.

In the New World, the United States emulated and learned from Great Britain at the start of industrialization: 'When the U.S. began to industrialize in the nineteenth century, she was following a path which had been blazed earlier by Great Britain. Much of the technology which was introduced into America during this period was in fact borrowed from that country, with varying degrees of modification' (Rosenberg, 1972, p. 59). To put it more bluntly, 'America started off as a copier' and 'stole British technology' (Thurow, 1985, p. 1). America, however, quickly pioneered, introducing numerous innovations of its own in the area of mass production and mass marketing. In other words, the US proved to be a strong 
second goose that was capable of eventually taking over the UK as the subsequent lead goose.

On the basis of historical evidence, therefore, it is reasonable to argue that any region can experience a similar phenomenon under a certain set of enabling conditions. At present, however, the Pax Americana has declined because of a diminished lead over the rest of the world, and there are no strong second geese like Japan and the NIEs in any other regions. ${ }^{4}$ Interestingly enough, the most noticeable FG formation currently in the making is within China itself. Industries are migrating from the coastal regions into the hinterland of that vast country (Bhalla and Qiu, 2004)

- in addition to less-developed adjacent countries such as Vietnam and Cambodia.

\subsection{RADELET AND SACHS' INTERPRETATION}

Radelet and Sachs (1997) recognize the significance of the FG theory by identifying it as one of the three major doctrines of development strategy:

. . . the 'flying geese' model, according to which countries gradually move up in technological development by following in the pattern of countries just ahead of them in the development process. In this vision, Korea and Taiwan take over leadership in textiles and apparel from Japan as Japan moves into the highertechnology sectors of electronics, transport, and other capital goods. A decade or so later, Korea and Taiwan are able to upgrade to electronics and auto components, while the textile and apparel industries move to Indonesia, Thailand, and Vietnam. .. (emphasis added, p. 52)

The FG model is clearly defined above as a process of sequential catchup in technological progress, one country following on the heels of more advanced countries up the ladder of 'technological development' - that is, tandem growth emanating from emulation and learning in industrial knowledge.

What institutional arrangements are necessary for a developing country to move forward in technological development? Radelet and Sachs explain the distinct institutional arrangements that were each specific to the three major doctrines of development strategy:

If the paradigmatic institution of the big push was state ownership of industry [as exemplified by the Stalinist drive toward rapid industrialization in the 1930s and China's Great Leap Forward of 1958-61], and for import substitution was private ownership backed by protectionism [as once seen throughout Latin America's inward-focused development strategy], for flying-geese development it is the export platform. The idea behind an export platform 
is to create an enclave economy hospitable to foreign investors and integrated into the global economy, without the problems of infrastructure, security, rule of law, and trade policies that plague the rest of the economy. Asian governments introduced several variations of the export platform, including export processing zones (EPZs), bonded warehouses, special economic zones, and duty drawback systems. Governments supported these institutions with macroeconomic policies that strengthened the incentives for labor-intensive exports, especially via appropriate exchange rates. (1997, pp. 52-3, emphasis added)

The big push approach was thus pursued in the interests of nationalistic self-reliance under communism and in isolation from the outside world. The import-substitution strategy, too, was carried out in an inwardfocused fashion avoiding integration with the global economy as much as possible. Both doctrines proved to be failures. In sharp contrast, the FG doctrine promotes integration with, and capitalization on, the outside world, by means of what Radelet and Sachs call 'capitalist enclaves' (p. 45) that serve as the bootstraps of catch-up development.

The enclaves, notably export processing zones (EPZs) and special economic zones, constitute the localized pockets of market capitalism, free from and unencumbered by the regulatory controls and political/bureaucratic constraints that prevail in the rest of the country - so as to be gradually and progressively integrated into the global economy that is currently molded by US-led capitalism. They are, therefore, attractive to foreign MNCs that can bring in all the necessary productive resources (such as technology, managerial skills, capital goods, and access to export markets) lacking at home. The enclaves are an institutional innovation that is pragmatically designed to introduce thorough reforms ('wipe the slate clean', so to speak) only in certain confined localities if such reforms are impractical for the entire economy. ${ }^{5}$ The entire institutions cannot be changed overnight, but they can be partially modified by creating enclaves. ${ }^{6}$

In short, Radelet and Sachs' interpretation emphasizes the establishment of 'capitalist enclaves' as a starting point for market reforms and integration with the global economy that 'stirs powerful forces for economic growth' (p. 46). However, it leaves unexplained the causal factors for technological upgrading and the sequence of technological development. It suffices here to note that in the post-World War II period a series of favorable developments in the Asian Pacific almost serendipitously coalesced into growth agglomeration in the form of de facto regional economic integration. It is a regional phenomenon feeding on synergistic interactions within that hierarchically clustered group of economies, a phenomenon that happens to have so far occurred only in the Asia Pacific in the recent past. 


\subsection{A 'FLYING-GEESE' WAY OF THINKING}

The global economy has seen a host of major events ever since the end of World War II. Among the momentous ones are the quick reconstruction and growth of postwar Japan as the world's second largest economy, the miraculous rise of the NIEs (despite their small size and resource scarcity), the recent rise of BRICs (Brazil, Russia, India, and China), the air and water pollution China now faces (just as Japan did in the 1960s), China's controversial resource diplomacy in some rogue African states (notably Sudan), an impressive reduction in Asian poverty, the rise of sovereign wealth funds, the soaring prices of commodities, and America's subprime mortgage meltdown. On the surface, these events seem to be unrelated happenings. Actually, however, they are interconnected and stem from the same common underlying forces. They are mere symptoms of the evolving global economy driven by US-led capitalism, as will be explored throughout this book.

Is there any economic development theory that can explain all these seemingly discrete events as integral parts of a big picture? Sure, there are a large number of theories on trade, investment, environmental issues, etc. But they are all discrete partial analyses, looking only at individual trees in the forest, so to speak. Here, the FG framework can help us join up the dots to understand the major undercurrent that has been sweeping and shaping the global economy.

\subsection{AGENDA}

Our agenda is as follows. Chapter 2 examines and interprets Akamatsu's original ideas that still remain to be elaborated and expanded. The importance of dialectical thinking is emphasized. Chapter 3 presents a stages (FG) model of industrial upgrading (that expands on, and reformulates, one of Akamatsu's three patterns of FG formation) by way of defining what has hitherto casually been called 'the ladder of economic development'. The intermediating factors that enable a catching-up economy to climb up the hierarchy of industrial activities are identified and analyzed. A concept of 'hegemon-led growth clustering' is presented as a new paradigm of regionalized growth and structural transformation. Different regions vary in their capabilities to capitalize on such growth opportunities. 'Stages jumbling' and 'time and space compression' are the accompanying results of the spread of industrial upgrading under US-led growth clustering.

Chapter 4 examines the record of poverty reduction in East Asia. A comparative-advantage-recycling (FG) model of labor-intensive 
manufacturing, in which comparative advantage in such manufacturing is being relayed from one economy to another down the East Asian hierarchy of countries, captures the core mechanism of poverty alleviation. An appendix to Chapter 4 provides an empirical test of 'market recycling' (or comparative-advantage recycling) in the US import market for a labor-intensive good, TV sets.

Chapter 5 introduces a stages (FG) model of infrastructure development. It explains why any country at the stage of heavy and chemical industrialization engages in an aggressive search for natural resources, as once carried out by the advanced West under colonialism, and recently by Japan during its resource-intensive industrialization of the 1960s and the 1970s. China's voracious appetite for energy and industrial commodities - and their China-driven run-ups in commodity prices - can be equally explained in terms of an FG stages theory. Chapter 6 looks at another developing region, Latin America, and asks the question: What is holding it back from benefiting as much from US-led global capitalism as Asia has done? This helps us understand the critical features, notably the institutional factors, of Asia's catch-up growth on a comparative basis.

The subsequent two chapters direct attention to the erstwhile neglected side of the FG theory, the financial dimension. Chapter 7 is concerned with the open-economy finance of economic development. A new concept, 'borrowed growth', is proposed to examine the benefits and perils of currentaccount-based finance. Such finance is also explained in terms of a stages (FG) model of development finance that can shed light on the boom-andbust of economic activity. 'Borrowed growth' is the driving force of US-led growth clustering. Chapter 8 takes up America's role as the leading innovator in financial services by studying the recent growth of private equity (venture capital and leveraged buyout firms) as a prime example. A stages (FG) model of corporate finance serves as the basic framework for analysis in elucidating the stages-differentiated features of corporate finance and the 'perverse' flow of capital from the developing to the advanced world (the 'Lucas-Schulz' paradox).

\section{NOTES}

1. 'Together under the Sun: A Survey of the Yen Bloc', Economist, July 15, 1989.

2. Andrew Tanzer, 'Ride It! You Can't Fight It!', Forbes, August 12, 1996, pp. 46-7.

3. One major difference is that a cascade maintains permanent relations between upstream and downstream positions, whereas a FG formation allows for exchanges in leadership.

4. The potential regions exist, however; they are the Americas, if NAFTA is extended throughout Latin America, and Eastern and Central Europe once they successfully shift to the market system. 
5. Radelet and Sachs (1997) hone in on this point:

If there is anything to the 'Asian miracle,' it is that several governments, benefiting from Japan's early experience and from each other's experience since the 1960s, have been able to create an economic environment for profitable, private investment - almost always with important foreign partners - despite serious shortcomings in overall political and economic conditions. They did so, in most cases, by creating in the midst of weaker economic institutions a capitalist enclave that has gradually spread throughout the economy. Put another way, Asia's challenge, so far accomplished, has been to create a virtuous circle, in which a modern economic sector originally confined to an enclave has not only expanded through new investments but has fueled a much broader modernization of political and economic institutions ... . global capitalism stirs powerful forces for economic growth even in the face of serious limitations in law, economic structure, and politics. (pp. 45-6, emphasis added).

6. It is interesting to note that the idea of 'a modern economic sector originally confined to an enclave' is now clearly promoted and applied by Sachs to UN-initiated economic development projects in Africa. As part of the UN Millennium Project on poverty reduction Sachs initially set up 12 'research villages' in ten African countries and soon added another 66 villages. These villages are designed as the 'modern sectors' that are provided with 'fertilizer and seed to improve food yield; anti-malarial bed nets; improved water sources; diversification from staple into cash crops; a school feeding programme; deworming for all; and the introduction of new technologies, such as energy-saving stoves and mobile phones' ('African Poverty: The Magnificent Seven', Economist, April 29, 2006, pp. 51-2). 
Terutomo Ozawa - 9781781950913 Downloaded from PubFactory at 04/26/2023 12:40:33PM via free access 